\title{
Aquaponics as an emerging production system for sustainable production
}

\begin{abstract}
With the increase in the consumption of vegetables due to the increase in the population and the tendency to change the consumer's eating habits, the demand for water in the production process of these foods also grows, requiring the production systems more efficient in terms of space utilization and natural resources. Aquaponics has gained attention for being considered a sustainable system that uses the residues of the creation of aquatic organisms for the cultivation of plants, thus having a water and nutrients recycling, in addition to the possibility of having a vertical distribution, optimizing the space. This production system is very interesting due to the possibility of being implemented in homes, serving as a complement to a family's diet, and the surplus can be sold in nearby markets, contributing to the local microeconomics, in addition to issues involving human health and nutrition, valuing local culture and environmental education. Following the Sustainable Development Goals (SDGs) established by the UN, this food production technique fits into the "Zero Hunger and Sustainable Agriculture" objective, as it provides quality food, closer to the consumer and produced with low inclusion of industrial fertilizers, in addition to recognized by FAO as a potential alternative to Smart Agriculture for the climate (Climate-smart agriculture-CSA). However, for its implantation on a commercial scale in the country, it is necessary to carry out adequate studies on planning and marketing, aiming to define strategically which are the markets that can be served by the products of the aquaponic systems, and also on what possibilities can be created or models should be structured considering the technology used within the system.
\end{abstract}

Keywords: substantiable system, food quality, human nutrition, climate-smart agriculture, nutrient cycling, use efficiency, microeconomics
Volume 4 Issue 5 - 2020

\author{
Thaís da Silva Oliveira,' Letícia Fernanda \\ Baptiston, ${ }^{2}$ Jéssica Pacheco de Lima' \\ 'Aquaculture Center of University of São Paulo (CAUNESP), \\ University of State of São Paulo, Brazil \\ ${ }^{2}$ College of zootechnics and food engineering (USP-FZEA) \\ University of São Paulo (USP), Brazil
}

Correspondence: Thaís da Silva Oliveira,Aquaculture Cente of University of São Paulo (Caunesp), Access Road Prof. Paulo Donato Castellane, Jaboticabal, São Paulo, Brazil,

Tel (16)3209-7477,Email thais.sila@unesp.br

Received: August 27, 2020 | Published:September 28, 2020

\section{Aquaponics as an alternative for growing vegetables}

The vegetable consumption has been expanding due to factors such as population growth, changes in consumer eating habits and other behavioral trends in the population. In addition, the consumer of vegetables is becoming more demanding, and it is necessary to increase the quantity produced and also the quality of this product, such as, for example, clean production and the implementation of an organic production system, but which maintains the supply throughout the year. With the increasing consumption of food, there is still a significant impact on the demand for water. Studies point out that in Brazil almost half of the water used in agriculture is wasted, which imposes enormous pressure on the sectors involved in food production, in which the optimization of space and natural resources is done development of integrated production systems is necessary. ${ }^{2,3}$

The aquaponics (Figure 1), fits into a technological production system, which has as bases, the recycling of water and nutrients present in it, which come from the feeding of fish in cultivation., From this technological system, it is possible to create aquatic organisms integrated with the hydroponics system, so that there are mutual benefits within the aquaponic system and optimization of the resources used such as space, energy, water and fertilizers. ${ }^{6,7}$

Fish residues are used as fertilizers for plant production, and their cultivation acts to remove compounds, especially nitrogenous, which in excess can harm the development of fish, acting on the quality of the water used in fish farming. ${ }^{4,6,8,9}$ Inorganic nitrogen fertilizers also have high values, which leads to high costs of agricultural production. ${ }^{10}$
The circulation of nutrients begins with the feeding of the fish, and the protein in the diet is excreted by the organisms in the form of ammonia (NH3 and $\mathrm{NH} 4+$ ), which is oxidized to nitrite (NO2-) by the oxidizing bacteria and then converted to nitrate $\left(\mathrm{NO}^{-}\right)$by nitrifying bacteria (Pseudomonas, Nitrosomonas and Nitrobacter). The aquaponics is conceptualizingas a technique that integrates aquaculture and hydroponics in a closed symbiotic cycle, in which aquatic organisms serve as a fertilizer supplier, and plants as water purifiers. ${ }^{11}$

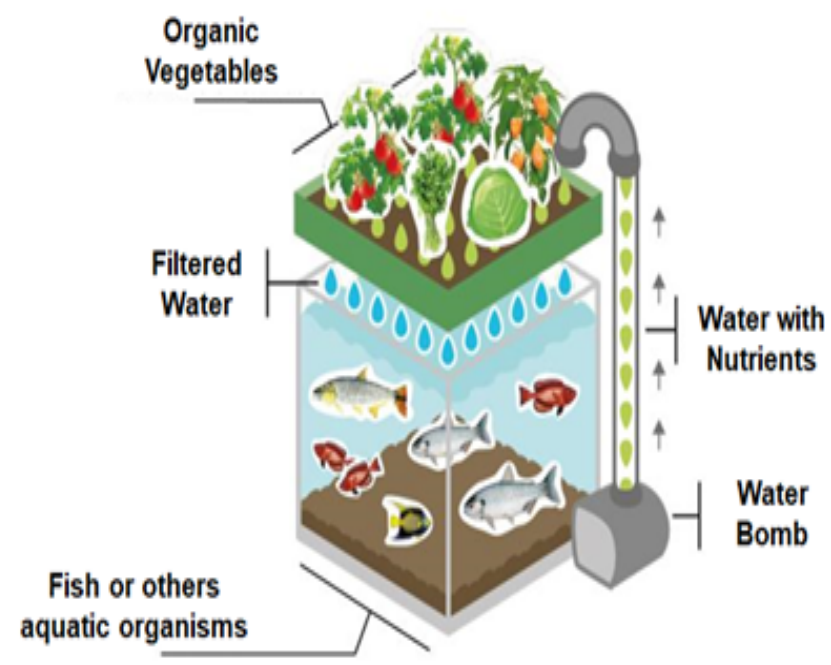

Figure I Aquaponic system (Illustration: vicente henrique). 
The aquaponics has gained attention as a biointegrated food production system that can be performed in large-scale recirculation systems (Figure 2), or even in homemade systems for own consumption (Figure 3). ${ }^{12}$ This production system offers a series of benefits for being an integrated cultivation modality, where a second crop uses the wastes of a first crop for its benefit and for the benefit of the environment. ${ }^{13}$ In addition, because water is reused, ${ }^{6}$ there is a decrease in the use of inorganic fertilizers, improving health and supplying food for human nutrition and poverty reduction.

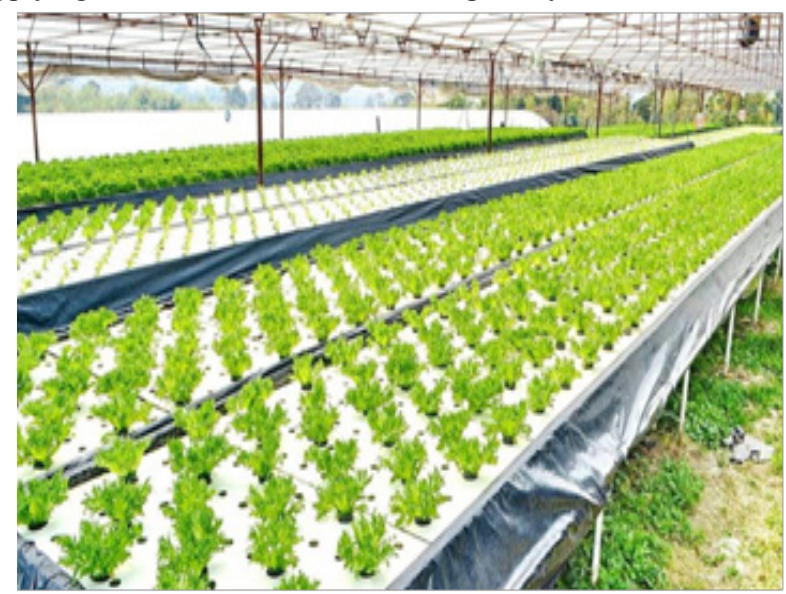

Figure 2 Aquaponic system commercial (Font: https://www.ciclovivo.com.br).

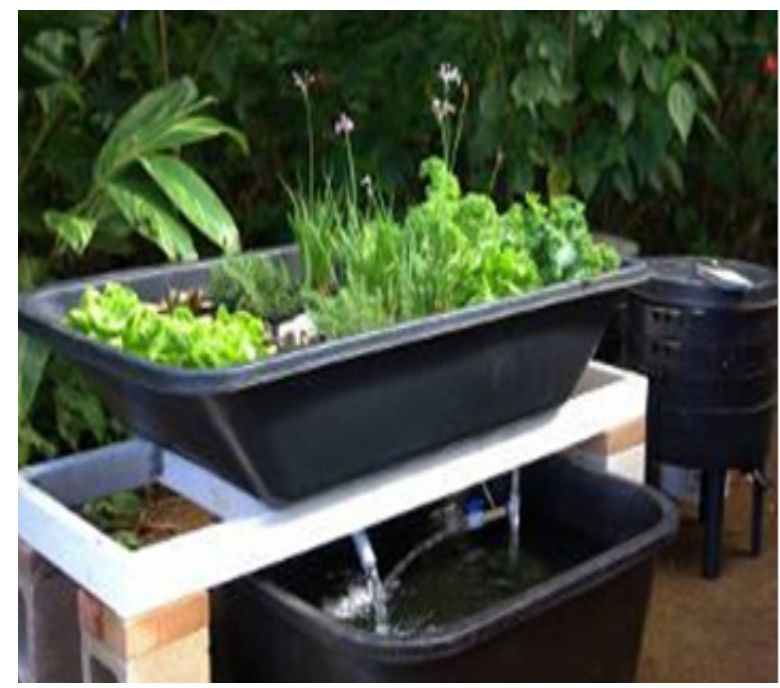

Figure 3 Homemade aquaponic system (Font: Federal University of Paraná).

Other cultural and social aspects within the aquaponic system can also be addressed, such as, for example, the valorization of local culture and, mainly, environmental education, factors that linked to the commercialization capacity of the final products obtained in the aquaponic system, contribute to the development sustainable ${ }^{14-16}$ (BUSS et al, 2015). Many studies are being developed, considering aquaponics as an emerging technology, being this modality an alternative to produce food in a more sustainable way. ${ }^{4}$

The aquaponic system can have different layouts, distributions, dimensions and technologies, directly affecting the value of the initial investment. However, for its implementation one must have a minimum knowledge about the biology of the species to be introduced in the system. Since fish and plants depend on the same water, both need adequate temperature, availability of nutrients and specific $\mathrm{pH}$ levels. ${ }^{17}$
Many studies are developed to prove the economic viability of aquatic vegetable and aquatic organism production. .,6, $18-21^{\text {Was }}$ investigated the viability of aquaponic production in the state of Hawaii through a case study carried out on three producing farms, the study found that even small scale production farms obtained profitable rates, indicating that aquaponics can be a viable option for the production of vegetables and fish for local markets. ${ }^{22}$ Another study was analyzed an integrated tilapia and lettuce production system, considered a practical and profitable enterprise. ${ }^{23}$ However, some studies report that if this production system is not implemented and managed correctly, resulting in unprofitable production. ${ }^{24}$ Another relevant factor is the inclusion of small producers, family farmers and women in the productive environment. As it is a clean production technology and without the need for a lot of labor, the system's adhesion becomes increasingly greater, being for own consumption or supplementing the family income.

These studies show that the aquaponic system can be profitable, however, requiring greater visibility and public perception of aquaponics..$^{25}$ since most researchers address factors such as reducing the cost linked to the system, when marketing studies and consumer behaviors could be implemented, aiming to increase the visibility of the system. ${ }^{26,27}$ To implement sustainable food production systems that use more efficient technologies (such as aquaponics), it is essential to consider the structural factors in a broad way, in addition to the technical and physiological needs at the heart of food production and behavior consumption among consumers. ${ }^{4}$ Several authors highlight the importance of consumer feeling for the development of an aquaponic industry ${ }^{18,28-30}$ and for sustainable agriculture in general. ${ }^{31}$

The aquaponic system is still relatively new. ${ }^{4}$ The author found that in Europe there is public investment in research for the development of aquaponic systems, however in the case of using this system as a business enterprise, there is no incentive from investing agencies. Evidencing the need to increase the visibility and feelingof the whole public about the possibilities of the system, be it for recreation, but also as an alternative source of income. In Brazil, the system is even more beginner, however promising since universities and private companies are increasingly invested in the diffusion and creation of innovative technologies adapted to the condition of the country. However, in Brazil has commercial aquaponic systems that are already established and operating, as the INMED Aquaponics(southwest region), Aquanature, Aquaponia Hulha Negra, AQP Brasil (south region), among other systems.

The supply of high nutritional value foods to low-income consumers is currently one of the main objectives pursued, in order to implement and meet the Sustainable Development Goals (SDGs) established by the UN, which surround food security and better nutrition. ${ }^{32}$ The production and consumption of fish and vegetables can improve the sustainability of food systems ${ }^{4}$. Therefore, the use of sustainable systems that can be implemented in a homemade way, such as aquaponics, is a strategic alternative for food production, falling under the "Zero Hunger and Sustainable Agriculture" objective, as it provides quality food, closer to the consumer and produced with low inclusion of industrial fertilizers, in addition to being recognized by FAO as a potential alternative to Smart Agriculture for the climate (Climate-smart agriculture-CSA). ${ }^{33}$

\section{Conclusion}

Aquaponic systems are emergent production systems that enable the creation of aquatic organisms and the cultivation of vegetables, 
through the integration of production systems, which occurs by recycling nutrients in the water from fish, which have nitrogen compounds used by plants for its development. In this way, aquaponics has become an interesting system, which has commonly been built at home and studied worldwide, as a possibility of producing sustainable food, given the low inclusion of inorganic fertilizers, and the generation of alternative income.

However, for its implementation on a commercial scale in the country, it is necessary to carry out adequate studies on planning and marketing, aiming to define strategically which are the markets that can be served by the products of the aquaponic systems, and also on what possibilities can be created or models should be structured considering the technology used within the system.

Considering that fish consumption in Brazil is low, the use of an aquaponic system, even if recreational for families, can be an alternative to bring Brazilians closer to aquatic organisms, sustainable food production and still meet the Sustainable Development Goals defined by ONU.

\section{Acknowledgments}

None.

\section{Conflicts of interest}

The authors declare that there is no conflict of interest.

\section{References}

1. FAO. Agricultura irrigada sustentável no Brasil: Identificação de áreas prioritárias - Brasília, 2017

2. Carvalho AR, Brum OB, Chimóia EP, et al. Avaliação da produtividade da aquaponia comparada com a hidroponia convencional. Vivências. 2017;13(24):79-91.

3. König B, Janker J, Reinhardt T, et al. Analysis of aquaponics as an emerging system of technological innovation. $J$ of Cleaner Production. 2018;180:232-243

4. Pinho SM, Molinari D, Mello GL, et al. Effluent from a biofloc technology (BFT) tilapia culture on the aquaponics production of different lettuce varieties. Ecol Eng. 2017;103:146-153.

5. Castellani D, Camargo AFM, Abimorad EG. Aquaponia: aproveitamento do efluente do berçário secundário do Camarão-da-Amazônia (Macrobrachium amazonicum) para produção de alface (Lactuca sativa) e agrião (Rorippa nasturtium aquaticum) hidropônicos. Bioikos. 2009:23(2):67-75.

6. Goddek S, Espinal CA, Delaide B, et al. Navigating towards decoupled aquaponic systems: A system dynamics design approach. Water. 2016; 8(7):303-332.

7. Roosta HR, Afsharipoor S. Effects of different cultivation media on vegetative growth, ecophysiological traits and nutrients concentration in strawberry under hydroponic and aquaponic cultivation systems. Advances in Environ Biol. 2012;6(2):543-555.

8. Hundley GMC, Navarro RD, Figueiredo CMG, et al. Use of the effluen from the production of Nile tilapia for the growth of basil (Origanum basilicum) and marjoram (Origanum majorana) in aquaponics systems. Rev Bras de Agrop Sustl. 2013;3:51-55.

9. ANDA (Associação Nacional para Difusão de Adubos). Mercado de fertilizantes, janeiro-abril /2015

10. Matson J. Fisgando peixes e plantas. Scientific American Brasil 2008; S.1.] n. 89, 2008.
11. Diver S. Aquaponics: integration of hydroponics with aquaculture. National Sustainable Agriculture Information Service, 2006.

12. Hundley GC, Navarro RD. Aquaponics: the integration between fish farming and hydroponics. Rev Brasde Agrop Sust. 2013;3(2):52-61.

13. Buss AB, Meurer VN, Aquini EN, et al. Desenvolvimento da aquaponia como alternativa de produção de alimentossaudáveis em perímetro urbano. Seminário de Ensino, Pesquisa e Extensão - SENPEX, 6. 2017.

14. Rakocy JE. Aquaponics -integrating fish and plant culture. In: Tidwell JH, editor. Aquac Prod Syst. 1 ${ }^{\text {st }}$ edn. Oxford: Wiley-Blackwell, 2012.

15. Pinto HS. Você sabe o que é Aquaponia? Entenda como essa atividade pode auxiliar as estratégias de segurança alimentar e nutricional atuais. Brasília: Núcleo de Estudos e Pesquisas/CONLEG/Senado, agosto/2015.

16. Silva MF, Passel DV. Climate-smart agriculture in the northeast of Brazil: an integrated assessment of the aquaponics technology. Sustainabity. 2020;12:3734.

17. Bosma RH, Lacambra L, Landstra Y, et al. The financial feasibility of producing fish and vegetables through aquaponics. Aquac Eng. 2017;78:146-154.

18. Kuhnen ADR, Araujo GM, Silva RN, et al. Aquaponia como alternativa para o cultivo de peixes e hortaliças. In: Fórum Latino-Americano de Engenharia e Sustentabilidade, 14ed. Anais [...]. 2016; 882-889.

19. Jordan RA, Ribeiro EF, Oliveira FC, et al. Yield of lettuce grown in hydroponic and aquaponic systems using different substrates. Rev Bras de Eng Agric e Ambl. 2018; 22(8):525-529.

20. Quagrainie KK, Flores RMV, Kim HJ, et al. Economic analysis of aquaponics and hydroponics production in the U.S. Midwest. Journal of Appl Aquac. 2018;30(1):1-14.

21. Tokunaga K, Tamaru C, Ako H, et al. Economics of small-scale commercial aquaponics in Hawaii. J of World Aquac Soc. 2015; 46:20-32.

22. Baker A. Preliminary development and evaluation of an aquaponic system for the American Insular Pacific. Master's thesis, University of Hawaii at Manoa. 2010

23. Love DC, Fry JP, Li X, et al. Commercial aquaponics production and profitability: Findings from an international survey. Aquac. 2015; 435(1):67-74.

24. Tyson RV, Treadwell DD, Simonne EH. Opportunities and challenges to sustainability in aquaponic systems. HortTechnology. 2011;21(1):6-13.

25. Greenfeld A, Becker N, Mcilwain J, et al. Economically viable aquaponics? Identifying the gap between potential and current uncertainties. Rev Aquac. 2019;11(3):848-862

26. Short G, Yue C, Anderson N, et al. Consumer perceptions of aquaponic systems. HortTechnology. 2017;27(3):358-366.

27. Goddek S, Delaide B, Jijakli H, et al. Challenges of sustainable and commercial aquaponics. Sustainability. 2015;7(4):4199-4224.

28. Junge R, Konig B, Villarroel M, et al. Strategic points in aquaponics Water. 2017;9(3):1-9.

29. Vermeulen $\mathrm{T}, \mathrm{Kamstra} A$. The need for systems design for robust aquaponic systems in the urban environment. Acta Hortic. 2013;1004:71-78.

30. Sage C. Addressing the Faustian bargains of the modern food system: Connecting sustainable agriculture with sustainable consumption. Int. JAgric Sustain. 2012;10(3):204-207.

31. The state of food security and nutrition in the World 2018. Building climate resilience for food security and nutrition.

32. Climate-smart fisheries and aquaculture. 